\title{
Antioxidant status of lambs fed on diets supplemented with selenite or Se-yeast
}

\author{
K. Boldižárová1,3, L. Grešáková ${ }^{1}, \breve{S}^{\text {. Faix }}{ }^{1}$, M. Mellen ${ }^{2}$ and L. Leng ${ }^{1}$ \\ ${ }^{1}$ Institute of Animal Physiology, Slovak Academy of Sciences \\ Šoltésovej 4, 04001 Košice, Slovak Republic \\ ${ }^{2}$ Slovak Agriculture University \\ Tr. A. Hlinku 2, 94976 Nitra, Slovak Republic
}

(Received 28 June 2004; revised version 6 December 2004; accepted 18 March 2005)

\begin{abstract}
The effects of feed supplementation with inorganic and organic forms of selenium (Se) on the activities of blood glutathione peroxidase (GPx), superoxide dismutase (SOD) in erythrocytes as well as on total antioxidant status in plasma (TAS) were examined in lambs. Fifteen animals were divided into three groups and fed experimental diets for 3 months. The first group received the basic diet (BD) providing a daily intake $50.6 \mu \mathrm{g}$ of Se only. Diets for the second and third groups consisted of BD supplemented with selenium $0.3 \mathrm{mg} \cdot \mathrm{kg}^{-1}$ of DM in the form of sodium selenite or Se-enriched yeast and giving a total daily intake $278.6 \mu \mathrm{g}$ of Se per animal. Increases in Se concentrations in whole blood, plasma and red blood cells as well as in the activities of blood GPx were highly significant in both supplemented groups, but no differences could be found that were due to the form of Se administered. The activity of SOD in erythrocytes was found to be significantly higher in the selenite group of lambs compared with both groups given BD or Se-yeast. The total antioxidant status was significantly lower in the group given Se-yeast compared with animals on $\mathrm{BD}$, which might be explained by larger amounts of selenide continuously produced from body Se deposits. The presented results support the opinion on the pro-oxidative features of sodium selenite when it is utilized as an animal feedstuff additive.
\end{abstract}

KEY WORDS: lamb, selenium, glutathione peroxidase, superoxide dismutase, total antioxidant status

\section{INTRODUCTION}

Living organisms have developed a complex antioxidant network to neutralize the excess of reactive oxygen substances (ROS) formed in the metabolic processes. ROS formed by harmful oxidative reactions are removed via various non-enzymatic and

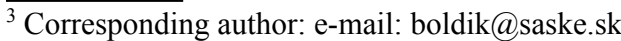


enzymatic antioxidative mechanisms including selenoenzymes. It is well documented that delivery of selenium (Se) as an essential trace element is the major factor affecting the activitites of Se-containing antioxidant enzymes in all tissues (Neve, 2000).

Changes in various antioxidant enzyme activities in cells have been used to assess the rate of oxidative stress. The antioxidative enzymes that have been most commonly examined are glutathione peroxidase (GPx) and superoxide dismutase (SOD). It is widely accepted that increase in SOD enzyme activity corresponds to enhanced resistance to oxidative stress (Fielding and Meydani, 1997). SOD converts superoxide radical into hydrogen peroxide while GPx as selenoenzyme catalyses the reduction of hydrogen peroxide and organic hydroperoxides (Arthur, 2000). Non-enzymatic antioxidants such as albumin, glutathione, ascorbic acid, $\alpha$-tocopherol, $\beta$-carotene, uric acid, bilirubin and flavonoids constitute an important part of the antioxidant network. Because the measurement of different antioxidant molecules separately is not practical and sometimes even impossible, the evaluation of antioxidant status based on total antioxidative capacity of plasma samples is widely used as an indicator of oxidative stress (Cao et al., 1993).

It is well known that optimal levels of Se in feedstuffs result in more efficient antioxidative protection and support the general maintenance of health in animals (Surai, 2000). In most countries the feedstuffs are very poor in Se, and so they are supplemented with various Se sources at the rate $0.2-0.3 \mathrm{mg} / \mathrm{kg}$ of dry matter. The routine source of Se used to supplement animal feeds is sodium selenite. However, this inorganic source of selenium has been shown to provide relatively low Se retention (Ortman and Pehrson, 1997; Surai 2002; Boldižárová et al., 2003; Kuricová et al., 2003). Currently increased attention is being paid to supplying animal feed with organic Se in the form of Se-yeast due to its larger bioavailability and formation of selenomethionine body deposits (Kuricová et al., 2003). On the other hand, excessive intake of selenium can result in increased production of reactive oxygen species with the associated consequences (Raisbeck, 2000).

The aim of this study was to compare the effect of feed supplementation with sodium selenite and Se-yeast on the activity of antioxidative enzymes glutathione peroxidase and superoxide dismutase. Concurrently the total antioxidant status of lambs was determined.

\section{MATERIAL AND METHODS}

\section{Animals, diet and treatment}

The experiment was carried out on 15 male lambs of Valaška breed at the age of four months divided into 3 groups of 5 animals and kept on diets that differed only 
in the content or the form of Se supplemented. Animals were housed in individual pens with free access to water and fed the all diets used for 3 months before the sampling. The lambs weighed from 18 to $20 \mathrm{~kg}$ at the end of experiment. The composition of the daily ration of basic diet (BD) per lamb and the daily delivery of Se by BD is presented in Table 1.

TABLE 1

The composition of the daily ration of basic diet per lamb and Se intake

\begin{tabular}{lcccc}
\hline Component & Amount & Dry matter & $\begin{array}{c}\text { Content of Se } \\
\mu \mathrm{g} \cdot \mathrm{kg}^{-1} \text { of DM }\end{array}$ & $\begin{array}{c}\text { Se intake } \\
\mu \mathrm{g} / \text { day }\end{array}$ \\
\hline Hay & $\mathrm{g}$ & $\mathrm{g}$ & 61.9 & 27.2 \\
Rapeseed oilmeal & 500 & 440.0 & 166.5 & 6.1 \\
Barley & 40 & 36.3 & 66.8 & 17.3 \\
Total & 300 & 259.0 & & 50.6 \\
\hline
\end{tabular}

The first group was given BD with the daily Se content of $50.6 \mu \mathrm{g}$ comming from the natural occurrence of Se in the dietary components only. The diet for the second group of lambs was the same BD plus Se supplement of $0.3 \mathrm{mg} \cdot \mathrm{kg}^{-1}$ of $\mathrm{DM}$ in the form of $\mathrm{Na}_{2} \mathrm{SeO}_{3}$ resulting in a final daily intake $278.6 \mu \mathrm{g}$ of Se. The third group received BD supplemented with $0.3 \mathrm{mg}$ of Se in the form of Se-yeast extract (Sel-Plex, Alltech Inc., USA) giving the same daily Se intake $278.6 \mu \mathrm{g}$ as in the $2^{\text {nd }}$ group of lambs. The diets for the $1^{\text {st }}$ and $2^{\text {nd }}$ groups were also fortified with adequate amounts of the yeast extract without Se (NUPRO, Alltech Inc., USA) to obtain the same final levels of the yeast extract as in the $3^{\text {rd }}$ group (daily intake $1.04 \mathrm{~g}$ of NUPRO in feed).

\section{Sample analysis}

Blood was collected from the jugular vein of animals into heparinized tubes at $6.00 \mathrm{a} . \mathrm{m}$. before the morning feeding. Plasma was removed after blood centrifugation at $1180 \mathrm{~g}$ for $15 \mathrm{~min}$. The red blood cells in the sediment were separated from the residual leukocytes and all the samples were kept at $-24^{\circ} \mathrm{C}$ until analysed. The concentrations of selenium in dietary components and samples of whole blood, plasma and red blood cells were measured by the fluorimetric method of Rodriguez et al. (1994).

Whole blood glutathione peroxidase (GPx) activity was determined as in Paglia and Valentine (1967) using the Ransel kit (Randox, UK). Haemoglobin (Hb) and total antioxidant status (TAS) (Miller et al., 1993) in plasma as well as superoxide dismutase (SOD) activity (Arthur and Boyne, 1985) in erythrocytes were analysed using kits from the same manufacturer (Randox, UK). 


\section{Statistical analysis}

Statistical analysis was done by one-way analysis of variance (ANOVA) with the post hoc Tukey multiple comparison test. The results are given as means \pm SEM.

\section{RESULTS}

Selenium concentrations in whole blood, plasma and red blood cells were highly elevated in both groups supplemented with sodium selenite or Se-yeast compared with the lambs fed the basic diet. No differences in Se levels in blood compartments were detected between groups fed diets enriched with selenium (Figure 1).

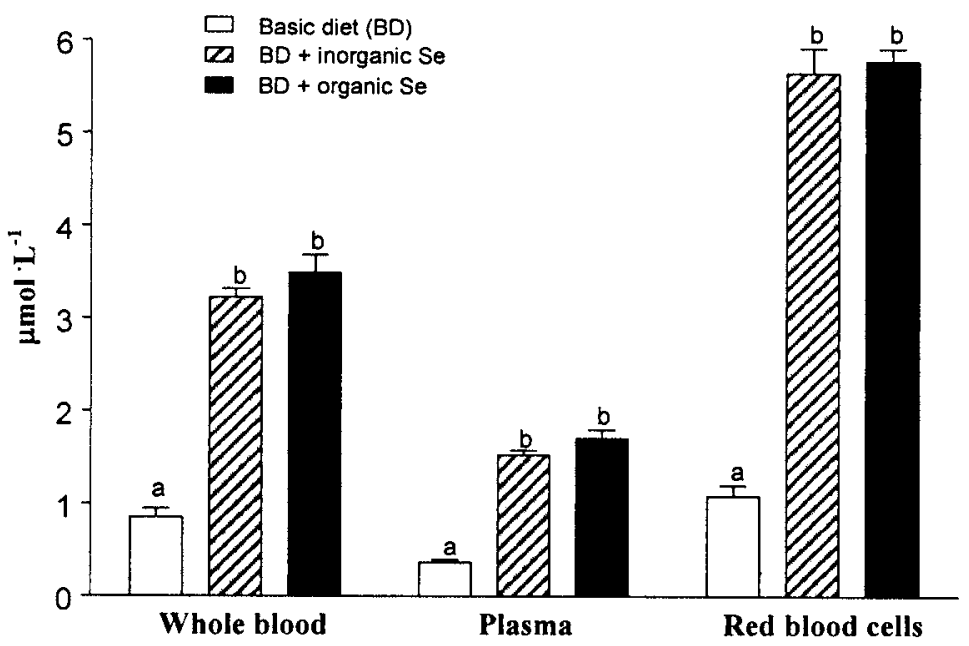

Figure 1. The effects of supplementing the feed with inorganic $\left(\mathrm{Na}_{2} \mathrm{SeO}_{3}\right)$ and organic (Se-yeast) form on the Se concentration in whole blood, plasma and red blood cells in lambs. Values are means $\pm \mathrm{SEM}$. Distinct letters above columns $=$ significant differences $(\mathrm{P}<0.001) . \mathrm{n}=5$ for each group

The activities of GPx followed the same pattern with highly significant increase in both Se supplemented groups. Again, no differences could be observed between the lambs given inorganic and organic selenium.

The activity of SOD in erythrocytes was the highest in the group receiving sodium selenite. A significant difference was noted between lambs fed the BD or Se-yeast diet compared with lambs fed a diet with inorganic Se.

A trend towards decline in the measured values of total antioxidant status was recorded in both groups given the Se-supplemented diets, but a significant difference appeared between BD-fed lambs and animals receiving Se-yeast only (Figure 2). 


\section{GPx}

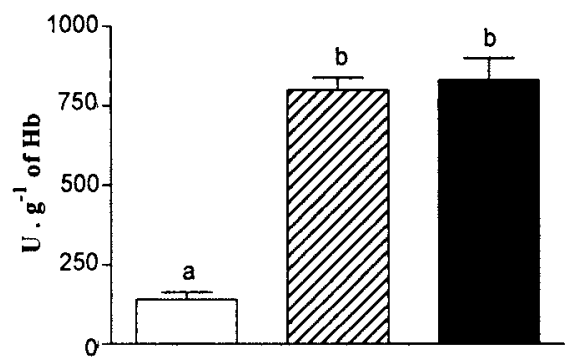

SOD

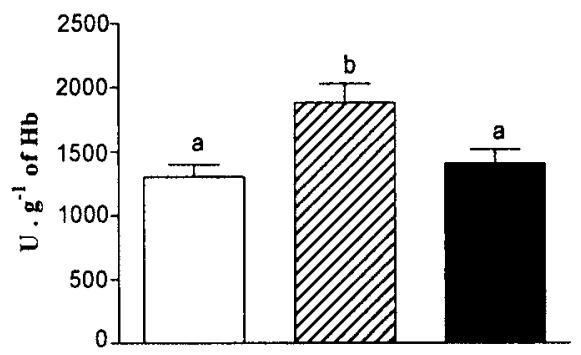

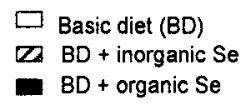

TAS

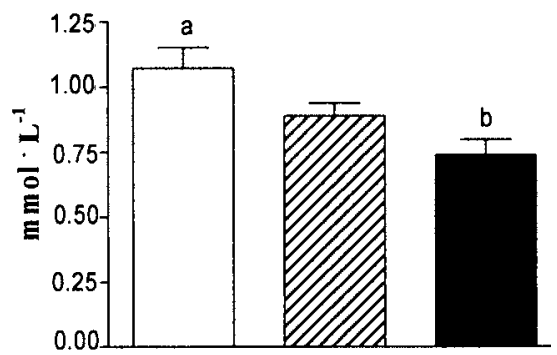

Figure 2. The effects of supplementing the feed with inorganic $\left(\mathrm{Na}_{2} \mathrm{SeO}_{3}\right)$ and organic (Se-yeast) form of selenium on the activity of blood glutathione peroxidase (GPx) and superoxide dismutase (SOD) in erythrocytes, and on the plasma total antioxidant status (TAS) in lambs. Values are means \pm SEM. Distinct letters above columns $=$ significant differences $(\mathrm{P}<0.001$ for $\mathrm{GPx}, \mathrm{P}<0.05$ for SOD and $\mathrm{P}<0.01$ for TAS). $\mathrm{n}=5$ for each group

\section{DISCUSSION}

The Se concentrations in whole blood, plasma and red blood cells were significantly elevated in lambs given Se supplements. Surprisingly, no significant differences due to the form of selenium supplied could be determined in these blood parameters. In contrast, Ortman et al. (1999) demonstrated significantly higher whole blood and plasma selenium levels as well as the blood GPx activity in dairy cows fed on diets with organic Se than in animals receiving the inorganic form of this microelement. The long-term dietary intake of organic Se by calves was found to result in markedly higher blood Se concentration than that produced even by parenteral administration of an equivalent amount of an inorganic selenium-containing drug used routinely for treatment of Se deficiency (Pavlata et al., 2001). Now we can only speculate about the reasons for such a discrepancy between our findings and the above-cited literature data, but the explanation might 
lie in the very low Se-status of the lambs at the beginning of our experiment due to low Se content in their BD (blood Se level $\left.0.85 \pm 0.1 \mu \mathrm{mol} \cdot \mathrm{L}^{-1}\right)$ and subsequent saturation of bodies with Se in supplemented groups. The experiment of Ortman et al. (1999) was done on adult lactating cows, while we measured the effects of various Se sources in young growing ruminants. We suspect that dilution of the selenium body pool due to growth of the lambs could also contribute to our findings on Se blood levels.

It is well documented that absorption of Se is much lower in ruminants compared with animals with simple stomachs. It has been suggested that the release of selenomethionine from Se-yeast added to feeds should correspond to the digestion of total proteins of feedstuff in ruminants. Rumen microorganisms can incorporate dietary selenomethionine into their own protein, but can also reduce dietary Se to insoluble forms such as elemental Se or selenides that are unavailable to absorption (Hakkarainen, 1993). Anyway, our recent results from the measurements of selenium balance showed the apparent absoption of $61 \%$ of Se in sheep given selenized yeast compared to $49 \%$ of selenium absorbed in animals fed a diet with equivalent amount of selenite (Leng et al., 2004). Recently attention has been paid to protect feedstuffs by making the proteins more resistant to microbial degradation in the rumen. Experiments with the mobile bag technique (De Boer et al., 1987) showed that appropriate heat processing of feeds could increase the proportion of their Se escaping digestive processes in the rumen, thus increasing the proportion of dietary amino acids potentially available for absorption in the lower parts of the digestive tract (van Ryssen and Schroeder, 2003).

Several authors have described a very high and linear correlation between Se concentration and GPx activities of blood and/or various tissues (Zachara et al., 1993; Harapin et al., 2000; Pavlata et al., 2001). The present results confirm the positive correlation between blood Se content and the activity of this selenoenzyme in blood. The Se supplementation increased the GPx activity in blood almost six times compared with the blood of lambs fed just the basic diet. However, no differences in blood GPx activities due to the chemical form of Se supplemented could be found in our experiment. This finding demonstrated that the activity of selenoenzyme GPx in blood was directly related to the blood Se concentration and only to the amount (not the form) of dietary Se intake in our experiment. Likewise our recent results have shown that the activity of blood GPx in young chickens was dependent on the total intake of selenium only, and no differences caused by its form in feeds could be noticed (Kuricová et al., 2003). The rational explanation for these findigs is based on the mechanism(s) of selenoenzyme synthesis. It is well known that all Se-compounds absorbed from the digestive tract must be converted into selenide before the selenocysteine is synthetized actually de novo for specific incorporation into the active centre of GPx (Schrauzer, 2000). 
The evident benefits of feed supplementation with Se-yeast resulting in considerably more effective Se utilization and retention of this microelement than in the case of supplementation with sodium selenite were demonstrated in our previous experiments (Grešáková etal.,2002; Kuricová et al., 2003).Despite the well-documented advantages of organic Se sources with high contents of selenomethionine, the inorganic sources of selenium are still widely preferred in many countries of the world as a supplement to animal feedstuffs. The utilization of selenite as a dietary supplement to improve the Se status of farm animals should be questioned for its considerable pro-oxidative features after its absorption from the digestive tract (Spallholz, 1997). It is well known that the activity of SOD is stimulated by increased superoxide radical generation associated with an increase in parameters of oxidation (Allen and Balin, 1989). The pro-oxidative properties of selenite could be the explanation for finding significantly increased activity of SOD in lambs supplemented with sodium selenite than in animals kept on the diet with the basic Se content only or with Se-yeast. Almost the same values of blood SOD activities in lambs given the basic diet or diet supplemented with organic Se suggest minimal pro-oxidative features of Se-yeast.

Measurements of plasma non-enzymatic antioxidants to assess in vivo antioxidant status showed the latter's decline in lambs given Se-supplemented diets, but a significant difference was recorded in animals fed diet with Se-yeast only. The interpretation depends upon the conditions under which the antioxidant status is determined, because the measurement reflects outcomes in a dynamic system. Prior and Cao (1999) reported that a decrease in antioxidant capacity of plasma may not necessarily be an undesirable condition if the measurement reflects decreased production of reactive species.

Our explanation of lower TAS in lambs fed on organic Se can be just a speculation based on contemporary knowledge of the metabolism of Secompounds absorbed from the digestive tract. The inorganic and organic $\mathrm{Se}$ species used as nutritional sources are transformed into the same intermediate, selenide, before being incorporated into selenoproteins (Esaki et al., 1981). This reduced form of Se was seen to be bound to plasma albumin by attaching to its disulphide bridges (Suzuki and Ogra, 2002). Albumin contribution to total plasma antioxidant activity is known to be about 43\% (Miller et al., 1993). The decreased TAS in lambs given organic Se might actually reflect the larger amount of selenide bound to albumin. One can ask why this would not be the case for lambs on the selenite diet too. Selenite is a very small molecule, and is absorbed rapidly and reduced by glutathione into selenide within a few minutes, then bound just temporarily to albumin before being transported to the liver for selenoprotein synthesis or methylation for subsequent excretion (Suzuki and Itoh, 1997). On the other hand, the long-term feeding of Se-yeast results in formation of selenomethionine deposits incorporated unspecifically into body 
proteins and its continuous release into the free amino acid pool with subsequent splitting into larger amounts of $\mathrm{H}_{2} \mathrm{Se}$ too. This continuously-formed selenide of selenomethionine origin is constantly delivered and bound to albumin, which was reflected in our experiment as lower TAS in plasma.

In conclusion, the increased SOD activity in erythrocytes of lambs fed on diets supplemented with sodium selenite confirm the data concerning its pro-oxidative properties when it is added to animal feedstuffs. The findings of lower total antioxidant status in animals given Se-yeast could be explained by larger amounts of selenide bound to albumin due to its continuous production from body selenium deposits.

\section{REFERENCES}

Allen R.G., Balin A.K., 1989. Oxidative influence on development and differentiation: An overview of a free radical theory of development. Free Radical Biol. Med. 6, 631-661

Arthur J.R., 2000. The glutathione peroxidases. Cell. Mol. Life Sci. 57, 1825-1835

Arthur J.R., Boyne R., 1985. Superoxide dismutase and glutathione peroxidase activities in neutrophils from selenium deficient and copper deficient cattle. Life Sci. 36, 1569-1575

Boldižárová K., Grešáková L', Faix Š., Levkut M., Leng L., 2003. Urinary selenium excretion in selenite-loaded sheep and subsequent Se dynamics in blood constituents. Reprod. Nutr. Develop. 43, 385-393

Cao G., Alessio H.M., Cutler R.G., 1993. Oxygen-radical absorbance capacity assay for antioxidants. Free Radical Biol. Med. 14, 303-311

De Boer G., Murphy J.J., Kennelly J.J., 1987. Mobile nylon bag for estimating intestinal availability of rumen undegradable protein. J. Dairy Sci. 70, 977-982

Esaki N., Nakamura T., Tanaka H., Suzuki T., Morino Y., Soda K., 1981. Enzymatic synthesis of selenocysteine in rat liver. Biochemistry 20, 4492-4496

Fielding R.A., Meydani M., 1997. Exercise, free radical generation, and aging. Aging Clin. Exp. Res. 9, 12-18

Grešáková L., Boldižárová K., Faix Š., Leng L'., 2002. The effects of different contents and form of selenium in feed on its balance in chickens. In: Proceedings of $20^{\text {th }}$ Days of Animal Physiology. Třešt' (Czech Republic), p. 12

Hakkarainen J., 1993. Bioavailability of selenium. Norway J. Agr. Sci., Suppl. 11, 21-35

Harapin I., Bauer M., Bedrica L., Potočnjak D., 2000. Correlation between glutathione peroxidase activity and the quantity of selenium in the whole blood of beef calves. Acta Vet. Brno 69, 87-92

Kuricová S., Boldižárová K., Grešáková L., Bobček R., Levkut M., Leng L., 2003. Chicken selenium status when fed a diet supplemented with Se-yeast. Acta Vet. Brno 72, 339-346

Leng L', Grešáková L'., Boldižárová K., Faix Š., Mellen M., 2004. Vplyv zdroja selénu v krmive na jeho retenciu u oviec. In: Proceedings of $21^{\text {st }}$ Days on Animal Physiology. Košice (Slovak Republik), p. 42

Nève J., 2000. New approaches to assess selenium status and requirement. Nutr. Rev. 58, 363-369

Miller N.J., Rice-Evans C., Davies M.J., Gopinathan V., Milner A., 1993. A novel method for measuring antioxidant capacity and its application to monitoring the antioxidant status in premature neonates. Clin. Sci. 84, 407-412

Ortman K., Andersson R., Holst H., 1999. The influence of supplements of selenite, selenate and selenium yeast on the selenium status of dairy heifers. Acta Vet. Scand. 40, 23-34

Ortman K., Pehrson B., 1997. Selenite and selenium yeast as feed supplements for dairy cows. J. Vet. Med. A 44, 373-380 
Paglia D.E., Valentine W.N., 1967. Studies on quantitative and qualitative characterization of erythrocyte glutathion peroxidase. J. Lab. Clin. Med. 70, 158-169

Pavlata L., Illek J., Pechová A., 2001. Blood and tissue selenium concentrations in calves treated with inorganic or organic selenium compounds - a comparison. Acta Vet. Brno 70, 19-26

Prior R.L., Cao G., 1999. In vivo total antioxidant capacity: comparison of different analytical methods. Free Radical. Biol. Med. 27, 1173-1181

Raisbeck M.F., 2000. Selenosis. Vet. Clin. N. Amer. - Food Anim. Pr. 16, 465-480

Rodriguez E.M., Sanz M.T., Romero C.D., 1994. Critical study of fluorimetric determination of selenium in urine. Talanta 12, 2025-2031

Schrauzer N.G., 2000. Selenomethionine: A review of its nutritional significance, metabolism and toxicity. J. Nutr. 130, 1653-1656

Spallholz J.E., 1997. Free radical generation by selenium compounds and their prooxidant toxicity. Biomed. Environ. Sci. 10, 260-270

Surai P.F., 2000. Organic selenium: benefits to animals and humans, a biochemist's view. In: T. P. Lyons, K.A. Jacques (Editors). Proceedings of Alltech's $16^{\text {th }}$ Annual Symposium "Biotechnology in the Feed Industry". Nottingham University Press, pp. 205-260

Surai P.F., 2002. Selenium in poultry nutrition - 1. Antioxidant properties, deficiency and toxicity. World Poultry Sci. J. 58, 333 - 347

Suzuki K.T., Itoh M., 1997. Metabolism of selenite labelled with enriched stable isotope in the bloodstream. J. Chromatogr. B 692, 15-22

Suzuki K.T., Ogra, Y., 2002. Metabolic pathway for selenium in the body: speciation by HPLC-ICP MS with enriched Se. Food Addit. Contam. 19, 974-983

Van Ryssen J.B.J., Schroeder G.E., 2003. Effect of heat processing of protein sources on the disappearance of their selenium from mobile bags in the digestive tract of dairy cows. Anim. Feed Sci. Tech. 107, 15-27

Zachara B.A., Mikolajczak J., Trafikowska U., 1993. Effect of various dietary selenium (Se) intakes on tissue Se levels and glutathione peroxidase activities in lambs. J. Vet. Med. A 40, 310-318

\section{STRESZCZENIE}

\section{Stan oksydacyjny jagniąt otrzymujących diety z dodatkiem selenitu lub drożdży z wbudowanym selenem}

Badano wpływ dodatku do dawek dla jagniąt nieorganicznej lub organicznej formy selenu (Se) na aktywność peroksydazy glutationowej (GPx) w krwi, nadtlenku dismutazy (SOD) w erytrocytach oraz na ogólny stan oksydacyjny w plazmie (TAS). Piętnaście jagniąt, podzielonych na 3 grupy, żywiono przez 3 miesiące dawkami doświadczalnymi. Grupa pierwsza otrzymywała dawkę podstawową (BD), zawierającą $50,6 \mu \mathrm{g}$ Se/dzień. Dawki dla grupy drugiej i trzeciej stanowiła pasza podstawowa (BD) uzupełniona Se w ilości $0,3 \mathrm{mg} \cdot \mathrm{kg}^{-1} \mathrm{~s} . \mathrm{m}$. w postaci seleninu sodu lub drożdży wzbogaconych w Se, tak że całkowita dzienna dawka Se wynosiła 278,6 $\mu \mathrm{g}$ na zwierzę. Stężenie Se w pełnej krwi, plazmie i czerwonych ciałkach krwi, jak i aktywność GPx w krwi były istotnie większe w obydwóch grupach doświadczalnych w porównaniu z kontrolną; nie stwierdzono natomiast różnic w tych wskaźnikach w zależności od formy dodanego Se. Aktywność SOD w erytrocytach była istotnie większa u jagniąt otrzymujących dodatek seleninu niż w grupie kontrolnej i z dodatkiem drożdży z wbudowanym selenem. Stan antyoksydacyjny był istotnie niższy w grupie otrzymującej selenowane drożdże niż w grupie kontrolnej, co można tłumaczyć większą ilością selenków powstających ciągle z zapasów Se w ciele.

Otrzymane wyniki potwierdzają opinię o pro-oksydacyjnych właściwościach seleninu sodu stosowanego jako dodatek paszowy dla zwierząt. 